\title{
Aurioral Rehabilitation in Consanguineous Cochlear Implanted Patients: Related Experience
}

Taguchi $\mathrm{CK}^{1^{*}}$, Santos RVS ${ }^{2}$, Almeida $\mathrm{LCM}^{2}$, Santos $\mathrm{LK}^{2}$, Silva $\mathrm{LMM}^{3}$, Santos MFS ${ }^{3}$, Silva AR ${ }^{4}$, Araujo BCL ${ }^{1}$, Lima $\mathrm{TRCM}^{5}$, Oliveira $\mathrm{AC}^{1}$

${ }^{1}$ Department of Audiology and Speech Therapist, Federal University of Sergipe (UFS), Brazil

${ }^{2}$ Audiologist, Federal University of Sergipe (UFS), Brazil

${ }^{3}$ Speech Therapist, Federal University of Sergipe (UFS), Brazil

${ }^{4}$ Department of Statistics and Actuarial Sciences of Federal University of Sergipe (UFS), Brazil

${ }^{5}$ Professional Postgraduate Program, Health Technological Management and Innovation of Federal University of Sergipe (UFS), Brazil

Corresponding Author: Carlos Kazuo Taguchi ${ }^{\text {ORCID ID }}$

Address: Universidade Federal de Sergipe, Avenida Marechal Rondon S/n - Vila Rosa Elze - São Cristóvão - SE, CEP: 49700-ooo; Email: carlostaguchi@hotmail.com

Received date: 16 June 2020; Accepted date: 11 July 2020; Published date: 31 July 2020

Citation: Taguchi CK, Santos RVS, Almeida LCM, Santos LK, Silva LMM, Santos MFS, Silva AR, Araujo BCL, Lima TRCM, Oliveira AC. Aurioral Rehabilitation in Consanguineous Cochlear Implanted Patients: Related Experience. Asp Biomed Clin Case Rep. 2020 Jul 31;3(2):166-70.

Copyright (C) 2020 Taguchi CK, Santos RVS, Almeida LCM, Santos LK, Silva LMM, Santos MFS, Silva AR, Araujo BCL, Lima TRCM, Oliveira AC. This is an open-access article distributed under the Creative Commons Attribution License, which permits unrestricted use, distribution, and reproduction in any medium provided the original work is properly cited.

\footnotetext{
Abstract

Introduction: Hearing loss causes comprehension difficulties, worsens speech perception and discrimination, and decreases the deaf quality of life.

Objective: To describe the results of variations in impedance measurements (IM) and the advances of hearing categories in cochlear implant (IC) patients.

Method: Qualitative, descriptive, and longitudinal study. Three consanguineous patients implanted and treated in speech therapy with aurioral approach. Telemetry of five-step neural responses was recorded, followed by impedance measurements, sound location tests, simplified Glendonald hearing detection procedure (GASP) tests, Ling sound tests, and recognition of vowels and words. All subjective measures classified the state of hearing categories that ranged 1 (no sound recognition and no oral communication) to 5 (sound localization and oral communication established). The follow-up period was 12 months.

Results: There was an overall increase in impedance measurements in all implanted ears. Training in sound localization, auditory memory, auditory closure, background figure, and temporal ordering skills promoted better speech performance. It was noticed that hearing abilities development was adequate because of restored social hearing and communication.

Conclusion: The variation of Impedance Measures was continuous and progressive and was concomitant and proportional to the performance improvement of hearing categories, ranging from condition 1 to 5 which improved oral communication in these cases.
} 
Citation: Taguchi CK, Santos RVS, Almeida LCM, Santos LK, Silva LMM, Santos MFS, Silva AR, Araujo BCL, Lima TRCM, Oliveira AC. Aurioral Rehabilitation in Consanguineous Cochlear Implanted Patients: Related Experience. Asp Biomed Clin Case Rep. 2020 Jul 31;3(2):166-70.

\section{Original Article}

\section{Keywords}

Cochlear Implantation, Deafness, Equipment and Supplies, Hearing Loss, Measurement Equipment

\section{Introduction}

Profound hearing loss leads to comprehension difficulties, worsening speech perception and discrimination, and decrease the patient's quality of life $[1,2]$.

Hearing loss could be repaired with the cochlear implant (CI), an electronic device surgically implanted in the inner ear that stimulates the auditory nerve. The Neural response telemetry (NRT) is the first measurement to verify the integrity of the implanted system and the electrical response of the auditory nerve stimulation [3].

To reach success on rehabilitation it's important to consider the age, aetiology, method of rehabilitation, auditory sensorial deprivation, motivation, and familiar involvement [4,5]. Rehabilitation with aurioral emphasis increases spontaneous speech within the first five months after CI activation [6]. Studies pointed out the importance of individualized and direct rehabilitation programs and the development of verbal skills procedures [6-8].

Due to the scarce reports about hearing abilities and rehabilitation progress in implanted deaf people [8].

\section{Objective}

This study aimed to describe the results in impedance measurements' changing and the advances of hearing categories in cochlear implant (IC) users.

\section{Method}

This project was approved by the Ethical Committee by number 31533814.0.0000.0065 and all subjects or their guardians signed Free and Informed Consent Form. Two females and one male, age ranging from 13 to 20 years with severe to profound bilateral sensorineural hearing loss and consanguinity evidence were included in this analysis. They use the same brand of devices and it will be present the variations in impedance measurements and the progress in auditory categories over a period of one year with aurioral rehabilitation. The NRT was recorded on an intraoperative act and it was performed four new adjustments named mapping on both ears. The first mapping, performed 40 days after the surgical implantation, provided a low electrical level to identify the dynamic area for each electrode and reached the minimum and maximum stimulation levels.

Three new programs were created with progressive increases of minimum and maximum levels to ensure acoustic comfort that was adjusted on speech therapy. It was performed the mapping 2, 3, 4, and 5 respectively after three, six, nine, and twelve months after activation to establish new programs that increased dynamic area offered loud stimulus and verified the impedance and telemetry measurements of the auditory nerve. In the same period, the revaluation of the auditory categories was performed to compare with the first one and show the progress in aurioral rehabilitation. It was used the following standard test: a) sound localization test; b) simplified test of the Glendonald Auditory Screening proceeding (GASP); c) the sounds of Ling; d) recognition of vowels and words test [9].

The speech therapy, based on the aurioral approach focused on sound detection, auditory discrimination, auditory recognition, and auditory comprehension. The revaluation of auditory categories was performed at therapeutic discharge.

\section{Results}

Table-1 shows the values of the IM of electrodes 3, 7, 11 , and 15 of the three patients. It is possible to verify telemetry measurements at surgical and discharge moments in the three rehabilitated cases. At surgery, it ranged from 1.9 to $12.4 \mathrm{~ms}$ in the right ear and from 1.4 to $9.6 \mathrm{~ms}$ in the left. At discharge, these values ranged from 3.7 to $13.5 \mathrm{~ms}$ in the right ear and 3.7 to $12.3 \mathrm{~ms}$ in the left, which means an increase of the impedance in the system. 
Citation: Taguchi CK, Santos RVS, Almeida LCM, Santos LK, Silva LMM, Santos MFS, Silva AR, Araujo BCL, Lima TRCM, Oliveira AC. Aurioral Rehabilitation in Consanguineous Cochlear Implanted Patients: Related Experience. Asp Biomed Clin Case Rep. 2020 Jul 31;3(2):166-70.

\section{Original Article}

Table-1: The impedance measurements on 3, 5, 11 and 15 electrodes in the both ears at the surgery and therapeutic discharge of the three patients

\begin{tabular}{|c|c|c|c|c|c|}
\hline & \multirow{2}{*}{ Electrode (E) } & \multicolumn{2}{|c|}{ Impedance Measure (MI): Surgery } & \multicolumn{2}{|c|}{ Impedance Measure (MI): Discharge } \\
\hline & & Rigth Ear & Left Ear & Rigth Ear & Left Ear \\
\hline \multirow{4}{*}{ Patient-1 } & E3 & $3.5 \mathrm{~ms}$ & $2.9 \mathrm{~ms}$ & $6.9 \mathrm{~ms}$ & $4.8 \mathrm{~ms}$ \\
\hline & E7 & $2.4 \mathrm{~ms}$ & $2.7 \mathrm{~ms}$ & $9 \cdot 3 \mathrm{~ms}$ & $11.5 \mathrm{~ms}$ \\
\hline & E11 & $2.4 \mathrm{~ms}$ & $2.7 \mathrm{~ms}$ & $9.6 \mathrm{~ms}$ & $9.9 \mathrm{~ms}$ \\
\hline & E15 & $3.2 \mathrm{~ms}$ & $1.4 \mathrm{~ms}$ & $8.5 \mathrm{~ms}$ & $8.2 \mathrm{~ms}$ \\
\hline \multirow{4}{*}{ Patient-2 } & E3 & $12.4 \mathrm{~ms}$ & $6.7 \mathrm{~ms}$ & $13.5 \mathrm{~ms}$ & $4.5 \mathrm{~ms}$ \\
\hline & E7 & $7.9 \mathrm{~ms}$ & $5.1 \mathrm{~ms}$ & $11.7 \mathrm{~ms}$ & $3.7 \mathrm{~ms}$ \\
\hline & E11 & $6.1 \mathrm{~ms}$ & $7.6 \mathrm{~ms}$ & $9.6 \mathrm{~ms}$ & $6.6 \mathrm{~ms}$ \\
\hline & E15 & $10.3 \mathrm{~ms}$ & $9.6 \mathrm{~ms}$ & $7.7 \mathrm{~ms}$ & $8.2 \mathrm{~ms}$ \\
\hline \multirow{4}{*}{ Patient-3 } & E3 & $2.1 \mathrm{~ms}$ & $2.1 \mathrm{~ms}$ & $4.0 \mathrm{~ms}$ & $4.8 \mathrm{~ms}$ \\
\hline & E7 & $2.1 \mathrm{~ms}$ & $2.1 \mathrm{~ms}$ & $3.7 \mathrm{~ms}$ & $4.8 \mathrm{~ms}$ \\
\hline & E11 & $2.1 \mathrm{~ms}$ & $2.4 \mathrm{~ms}$ & $10.7 \mathrm{~ms}$ & $10.9 \mathrm{~ms}$ \\
\hline & E15 & $1.9 \mathrm{~ms}$ & $1.9 \mathrm{~ms}$ & $10.9 \mathrm{~ms}$ & $12.3 \mathrm{~ms}$ \\
\hline
\end{tabular}

Table-2 shows the mean values of the impedance measurements captured in the implanted's devices of each patient at the surgery and discharge. Thus, respectively, we noticed that for patient 1 it ranged from 2.6 to $7.7 \mathrm{~ms}$ in the right ear and 3.1 to $8.6 \mathrm{~ms}$ in the left, for patient 2 it ranged from 8.9 to $11.2 \mathrm{~ms}$ in the right ear and 6.8 to $5.3 \mathrm{~ms}$ in the left and for patient 3 it ranged from 2.0 to $6.8 \mathrm{~ms}$ in the right ear and 2,4 to $7.5 \mathrm{~ms}$ on the left. It's possible to verify that these measures increased.

\section{Discussion}

It was noticed an increase in the auditory category that changed from 1 to 4 or 5 . Some variations of the impedance's values could be explained due to the absence of the pattern in the behaviour of the connective tissue on the auditory pathway [10]. Other studies related that changes in electrical stimuli threshold occur randomly without corresponding to a predetermined parameter [3,11,12].

The increase in impedances was agreed with a study suggested that the values of these impedances revealed the load distribution in the intracochlear electrode varies for neural fibbers excitation depending on the cochlear and neural topology [13].

Table-2: Mean values of all electrodes of both ears of the three patients at surgery and therapeutic discharge

\begin{tabular}{|l|c|c|c|c|c|c|}
\hline \multirow{2}{*}{} & \multicolumn{2}{|c|}{ Patient-1 } & \multicolumn{2}{c|}{ Patient-2 } & \multicolumn{2}{c|}{ Patient-3 } \\
\cline { 2 - 7 } & Surgery & Discharge & Surgery & Discharge & Surgery & Discharge \\
\hline Right Ear & $2.6 \mathrm{~ms}$ & $7.7 \mathrm{~ms}$ & $8.9 \mathrm{~ms}$ & $11.2 \mathrm{~ms}$ & $2.0 \mathrm{~ms}$ & $6.8 \mathrm{~ms}$ \\
\hline Left Ear & $3.1 \mathrm{~ms}$ & $8.6 \mathrm{~ms}$ & $6.8 \mathrm{~ms}$ & $5.3 \mathrm{~ms}$ & $2.4 \mathrm{~ms}$ & $7.5 \mathrm{~ms}$ \\
\hline
\end{tabular}


Citation: Taguchi CK, Santos RVS, Almeida LCM, Santos LK, Silva LMM, Santos MFS, Silva AR, Araujo BCL, Lima TRCM, Oliveira AC. Aurioral Rehabilitation in Consanguineous Cochlear Implanted Patients: Related Experience. Asp Biomed Clin Case Rep. 2020 Jul 31;3(2):166-70.

\section{Original Article}

The involvement of the patients and early auditory intervention and diagnosis contributed to success $[14,15]$. Face on a long period of sensory deprivation It was observed progress on auditory abilities, restauration the social hearing, and social communication. The training of sound localization, auditory memory, auditory closure, background figure, and temporal ordering was effective $[6,16]$.

These related cases were agreeing a study [17] which indicated that in the period of six months to one year of telemetry remained unchanged in the implantation process and showed a good correlation with the position of the $\mathrm{CI}$ in the inner ear.

The therapeutic progress in a short period of intervention provided an encouraging experience for patients, parents, and clinicians because improved the communication capacity of patients and optimizes the communication benefits provided by CI $[3,13,16]$.

\section{Conclusion}

The variation of Impedance Measures was continuous and progressive and was concomitant and proportional to the performance improvement of hearing categories, ranging from condition 1 to 5 which improved oral communication in these cases.

\section{Author Contribution}

Conception and design of the study, collection, analysis or interpretation of data: Carlos Kazuo Taguchi, Raissa Valença de Souza Santos, Lívia Caroline Menezes Almeida, Larissa Karoline Santos, Lúcia Maysa Muniz da Silva, Mateus Ferreira da Silva Santos.

Draft or critical review of important intellectual content: Carlos Kazuo Taguchi, Raissa Valença de Souza Santos, Allan Robert da Silva, Brenda Carla Lima Araujo.

Approval of the final version of the article to be published: Carlos Kazuo Taguchi, Raissa Valença de Souza Santos, Thales Rafael Correia de Melo Lima, Aline Cabral de Oliveira.

\section{Conflict of Interest}

All authors have read and approved the final version of the manuscript. The authors have no conflicts of interest to declare.

\section{References}

[1] Angelo TC, Moret AL, Costa OA, Nascimento LT, Alvarenga Kde F. Quality of life in adult cochlear implant users. Codas. 2016 Apr;28(2):106-12. [PMID: 27191872]

[2] Buarque LF, Brazorotto JS, Cavalcanti HG, Lima Júnior LR, Lima DD, Ferreira MÂ. Satisfaction of cochlear implant users with post-lingual hearing loss. Rev. CEFAC. 2014 Aug;16(4):1078-87.

[3] Moura AC, Goffi-Gomez MV, Couto MI, Brito R, Tsuji RK, Befi-Lopes DM, Matas CG, Bento RF. Longitudinal Analysis of the Absence of Intraoperative Neural Response Telemetry in Children using Cochlear Implants. Int Arch Otorhinolaryngol. 2014 Oct;18(4):362-68. [PMID: 25992123]

[4] Tefili D, Barrault GF, Ferreira AA, Cordioli JA, Lettnin DV. Cochlear implants: technological aspects and socioeconomic role. Revista Brasileira de Engenharia Biomédica. 2013 Dec;29(4):414-33.

[5] Sousa AF, Couto MI, Carvalho AC, Matas CG, BefiLopes DM. Word acquisition in children with cochlear implants. Revista CEFAC. 2014 Oct;16(5):1504-11.

[6] Lucchesi FD, Almeida-Verdu AC. Ensino de componentes da linguagem a usuários de implante coclear: Revisão da literatura. Revista CEFAC. 2017 Dec;19(6):855-67.

[7] Speri MRB. The child with hearing impairment: from suspicion to the process of rehabilitation speechlanguage pathology. Volant Verba. 2013;4(1):40-65.

[8] Neves AJ, Verdu ACMA, Moret ALM, Silva LTN. The implications of Coclear Implant for the development of language skills: a review of the literature. Revista CEFAC. 2015;17(5):1643-56.

[9] Moret AL, Bevilacqua MC, Costa OA. Implante coclear: audição e linguagem em crianças deficientes auditivas pré-linguais [Cochlear implant: hearing and language in pre-lingual deaf children]. Pro Fono. 2007 Jul-Sep;19(3):295-304. [PMID: 17934605]

[10] Burghard A, Lenarz T, Kral A, Paasche G. Insertion site and sealing technique affect residual hearing and tissue formation after cochlear implantation. Hear Res. 2014 Jun;312:21-27. 
Citation: Taguchi CK, Santos RVS, Almeida LCM, Santos LK, Silva LMM, Santos MFS, Silva AR, Araujo BCL, Lima TRCM, Oliveira AC. Aurioral Rehabilitation in Consanguineous Cochlear Implanted Patients: Related Experience. Asp Biomed Clin Case Rep. 2020 Jul 31;3(2):166-70.

\section{Original Article}

[PMID: 24566091]

[11] Isaiah A, Vongpaisal T, King AJ, Hartley DE. Multisensory training improves auditory spatial processing following bilateral cochlear implantation. J Neurosci. 2014 Aug 13;34(33):11119-30. [PMID: 25122908]

[12] Carvalho B, Hamerschmidt R, Wiemes G. Intraoperative Neural Response Telemetry and Neural Recovery Function: a Comparative Study between Adults and Children. Int Arch Otorhinolaryngol. 2015 Jan;19(1):10-15. [PMID: 25992145]

[13] Bicas RD, Guijo LM, Delgado-Pinheiro EM. Oral communication and auditory skills of hearing impaired children and adolescents and the speech therapy rehabilitation process. Revista CEFAC. 2017 Aug;19(4):465-74.

[14] Filippini R, Brito NFS, Neves-Lobo IF, Schochat E. Maintenance of auditory skills after hearing training. Audiol Commun Res. 2014;19(2):112-16.
[15] Mittmann P, Todt I, Ernst A, Rademacher G, Mutze S, Göricke S, Schlamann M, Ramalingam R, Lang S, Christov F, Arweiler-Harbeck D. Electrophysiological detection of scalar changing perimodiolar cochlear electrode arrays: a long term follow-up study. Eur Arch Otorhinolaryngol. 2016 Dec;273(12):4251-56. [PMID: 27351885]

[16] Bento RF, Brito Neto RD, Castilho AM, Gómez VG, Giorgi SB, Guedes MC. Auditory results with multicanal cochlear implant in patients submitted to cochlear implant surgery at University of São Paulo Medical School-Hospital das Clínicas. Revista Brasileira de Otorrinolaringologia. 2004 Oct;70(5):632-37.

[17] Gaylor JM, Raman G, Chung M, Lee J, Rao M, Lau J, Poe DS. Cochlear implantation in adults: a systematic review and meta-analysis. JAMA Otolaryngol Head Neck Surg. 2013 Mar;139(3):265-72. [PMID: 23429927] 